TITLE Scotland's Social Services Spending Needs: An English View

Authors $\quad{ }^{\mathrm{a}}$ David King (principal author); ${ }^{\mathrm{b}}$ Matthew Pashley; ${ }^{\mathrm{c}}$ Rob Ball

Affiliations ${ }^{a}$ Professor, Department of Economics University of Stirling; also consultant on local government and its finance to the OECD and the World Bank.

${ }^{\mathrm{b}}$ Research assistant, Department of Economics, University of Stirling.

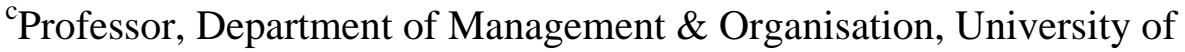
Stirling.

Contact (Principal author) Professor David King, Department of Economics, University of Stirling, Stirling FK9 4LA

E-mail: dnk1@stir.ac.uk

Tel: 01786467475

Fax: 01786467469

REVISED PAPER September 2006 


\section{SCOTLAND'S SOCIAL SERVICES SPENDING NEEDS: AN ENGLISH VIEW}

\section{ABSTRACT}

Scottish citizens enjoy 25\% more spending per head on public services than English citizens, but almost nothing is known about the countries' relative needs and hence about how far this gap is defensible. We explore their spending needs for local authority services, which cover over half the spending concerned. We first compare needs for local personal social services. To do so, we take the complex formulae with which the Westminster government assesses the needs of English local authorities, and we use these formulae to assess the needs of Scottish local authorities. The formulae suggest that Scotland needs $15.3 \%$ more per head than England. We then combine these results with those of two earlier papers that explore other local services to show that the English formulae put Scotland's per capita needs for local authority services as a whole at about 6\% above England's. However, we also compare the relative needs of Scottish local authorities as assessed by the English formulae with their relative needs as assessed by the Scottish needs formulae currently used by Holyrood, and we find major differences. This suggests either that at least one country assesses needs with seriously flawed formulae, or that the two countries have different conceptions of need.

\section{Introduction and background}

Individuals, communities and enterprises in Scotland receive more public spending per head than those in England. They receive 12\% more on transfers and 25\% more on public services (HM Treasury, 2004, Table 6.7, 8.9a and A11). The transfers, such as state pensions and jobseekers' allowance, are based on UK-wide policies, so the excess that Scotland enjoys with them over England must reflect a government view that Scotland has higher needs.

However, the different levels of spending on public services in the two countries do not stem from assessments of needs. Public services in Scotland are mostly provided by new Scottish Parliament in Holyrood, and were before handled by the Scottish Office. When this separation arose in the $19^{\text {th }}$ century, Scotland was allocated $11 \%$ of the total amount available 
for UK services, which roughly reflected its then population share. But the spending share was maintained for many years even though Scotland's population share fell.

In the 1970s, the Chief Secretary to the Treasury, Joel Barnett, devised a formula for allocating each year's increase in public spending. This formula has led to Scotland receiving less than $11 \%$ of each year's increase, so relative spending in Scotland is lower now than it was then. But, as we have seen, Scotland still has a considerable funding advantage. Many people, including Barnett himself (quoted in Twigger, 1998, 17), argue that the present formula should be replaced with a Barnett formula Mark II that was based on spending needs. More recently, Mackay and Williams (2005) point out that, by ignoring relative need, the Barnett formula creates inconsistency, and Bristow et al (2005) argue that the pressure for its reform would become even stronger if regionalization in England went ahead.

Some people dissent from this broad consensus. For example, Midwinter (2003) argues that the Barnett formula gives stability. And McLean and McMillan (2003) advocate distributing public funds between regions on the basis of needs as implied by the inverse of their gross domestic products rather than detailed assessments of needs for individual services.

However, one problem for all these previous participants in this debate about the relative levels of spending in Scotland and England is the lack of any detailed study that compares their spending needs for public services. Our purpose in this paper is to inform the debate by attempting to make some detailed comparisons of their spending needs. The current paper is one of three where we compare their needs for different local services. These papers give the only detailed comparison of the countries' needs for any public services that has ever been made, and so give a unique insight into this major debate. 
Different people hold different views about needs, so if we devised our own formulae for assessing needs, then our formulae could be challenged and their results dismissed. But we do not have to devise formulae for assessing relative needs for local authority (LA) services, because each LA's relative needs are already assessed, in England by the Office of the Deputy Prime Minister (ODPM) and in Scotland by the Scottish Executive (SE). ${ }^{1}$ The ODPM and SE use their own different formulae, but these formulae have been developed over many years and can be taken to have some support. So comparisons based on them should be harder to dismiss. Although using these formulae means that we consider only local government services, these between them are the most important ones, for they account for some $60 \%$ of spending on government services.

The ODPM estimates are called Formula Spending Shares (FSSs) while the SE estimates are called Grant Aided Expenditures (GAEs). Both the ODPM and the SE give each LA a figure for its spending needs, but they stress that their figures cannot be taken to indicate absolute need and instead indicate only relative needs (ODPM, 2002, paragraph 10; Scottish Parliament, 2002). This qualification does not matter for our research because we are concerned only with relative needs - those for Scotland and England.

In King et al, 2004, we looked at the largest component of LA spending, education, and found that if the ODPM's approach to assessing education need was adopted in Scotland, then Scotland would be found to need to spend perhaps only 3\% per pupil more. However, as Scotland has $25 \%$ more public spending per head on services in total, we decided to look

\footnotetext{
${ }^{1}$ From 2006, the work of the ODPM was moved to the new Department of Local Government and the Regions.
} 
at other LA services, and this paper takes personal social services (PSS) which are the second largest component of LA spending. We have written a third paper (King et al, 2006), which looks at all the small local services except police.

In the present paper, we estimate the 2004-05 FSS for PSS of each Scottish LA. We then sum these LA figures to find the FSS for PSS in Scotland as a whole, and we compare this with England's FSS for PSS. We have tried to assess exact Scottish FSSs to give an accurate comparison. $^{2}$

Section II below notes the contexts in which the FSS and GAE formulae operate. Section III briefly reviews these formulae. Sections IV, V and VI respectively apply to Scotland the FSS formulae for PSS for children, PSS for older people and PSS for younger adults. Section VII compares our estimates of FSS for PSS in Scotland with the ODPM's figures for England. It also compares relative FSSs between local authorities with their relative GAEs. Section VIII gives our conclusions.

\section{The context of the needs formulae}

The ODPM and SE calculate all their FSS and GAE figures for each LA in order to calculate the amount of block grant that they will pay to each LA. And although FSSs and GAEs are

\footnotetext{
${ }^{2}$ In each country, the needs formulae are subject to annual modification, yet any analysis like ours has to relate to a single year. We chose 2004-05 as this was the latest year for which we were able to obtain data when we did our research. Since then, there have been no significant changes to Scotland's GAE formulae. However, in April 2006, England's FSS formulae were replaced by new relative needs formulae which were required following changes to the way in which central government supports local education spending (see ODPM, 2006). For PSS, the revised new formulae used virtually identical indicators to FSS, with virtually identical relative weights, so more recent comparisons would yield very similar results to ours.
} 
presented as measures of relative need, in practice the total FSS or GAE figure for each LA is taken as an estimate of its need to spend, net of any specific grants which it receives.

To calculate an LA's total FSS, the ODPM first estimates a separate FSS for each of the following: education; PSS; police; fire; highway maintenance; environmental, cultural and protective services; and capital financing. It then sums these figures. In this paper, we estimate what each Scottish LA's FSS for PSS would be if FSSs were used in Scotland.

We also want to compare the GAE and FSS formulae. Unfortunately, we cannot do this by comparing the PSS needs that the FSS approach would give Scottish LAs with the PSS needs - or social work needs as they are called in Scotland - that the GAE does give them. This is because Scottish LAs operate within a framework laid down by Holyrood while English LAs operate within a framework laid down by Westminster. The frameworks differ in policy details and in the use of specific grants. So it is hard to say just how far any differences between a Scottish LA's FSS for PSS and its GAE for social work result from differences in its estimated need, and how far they result from the different frameworks. However, while the different frameworks make it hard to compare the absolute levels of need assessed by the two formulae, we can compare their estimates of relative need between Scotland's LAs.

\section{An overview of the FSS and GAE approaches to PSS}

The FSS approach used in England differs from the GAE approach used in Scotland because over many years the former has been evolved by the Westminster government and the latter by the Scottish Office and, more recently, the SE. The FSS system estimates each LA's total FSS for PSS as the sum of its needs for three main components or 'sub-blocks' of PSS which concern children, older people and younger adults. 
Table 1 shows these sub-blocks and the percentage share in England as a whole that each sub-block has of the total FSS for PSS. Table 1 also shows the main factors which determine the FSS given to each LA. FSS is discussed in more detail in Sections IV to VI.

The GAE approach breaks the need to spend on PSS into many components. The ten main ones account for $90.9 \%$ of the total GAE for PSS. Table 2 lists these and gives their shares. The 9.1\% for 'other' services covers components for AIDS/HIV cases, community care for the mentally ill, community care action plans, and a children's services development fund. Each component's GAE is based on one or more indicators, and Table 2 shows the main indicators, with IS standing for Income Support and IBJSA for Income Based Jobseekers’ Allowance. The GAE also has an island allowance for Eilean Siar, Orkney, Shetland and some other LAs with islands. But, overall, GAEs depend on fewer indicators than FSSs.

In short, FSS divides spending into three blocks, and looks at a wide range of indicators that may affect spending on each block. In contrast, GAE divides spending into many components, and looks at only a few indicators that clearly affect spending on each.

Essentially the formulae differ in the choice of indicators and their relative importance. In principle, there might be some indicators which are not relevant in England, and which FSS therefore ignores, but which are relevant in Scotland. If this was so, then applying FSS to Scottish LAs would necessarily give flawed results. However, looking at the indicators in Table 2 which Holyrood allows for GAE, there do not seem to be any which would apply only in Scotland. And if Holyrood has not identified any such factors, then we do not feel that this is a valid objection to applying FSS to Scottish LAs. 
Another issue is whether some factors have more affect in one country than another. For example, suppose that needs depended more on the number of people on income support in one country than the other. Then, again, applying one country's formulae to the other could be give misleading results. But looking at Table 1 , there is no reason to suppose that the indicators allowed for in FSS would have fundamentally different impacts in Scotland. Indeed, it would be surprising if, for example, the weights that the ODPM applied to Cumbria were felt wholly inappropriate to neighbouring Dumfries and Galloway.

\section{The FSS sub-block for children and its application to Scotland}

As noted, each LA's FSS for PSS is the sum of its FSS for the three PSS sub-blocks, which concern children, older people, and younger adults. The 2004-05 FSS formulae are detailed by the ODPM (2004a, 23-26 and 64-68). This section applies the children’s sub-block formulae to each Scottish LA, and it also sums the figures for all Scotland's LAs to give totals for Scotland as a whole. Our tables put the Scottish total figures above the individual LA figures. Sections V and VI apply the formulae for the two other sub-blocks to Scotland.

For comparison purposes, our tables in each section also show the FSS for England as a whole and the FSS for six individual English LAs (using data from ODPM 2004a, 2004b and 2004c). The authorities chosen include Tower Hamlets, which has the highest FSS per head for PSS, and Wokingham, which has the lowest. The others, Westminster, Liverpool, Leicester and Herefordshire, have FSS per head figures for PSS that range widely between those of Tower Hamlets and Wokingham. 
The sub-block for children covers the provision of PSS for children aged 0-17. Tables 3 and 4 show how the needs per child, as estimated by FSS, vary between LAs. The following paragraphs indicate the factors involved: Appendix 1 gives our sources for Scottish LA data.

The basic sum per child

The FSS formula begins by allowing a basic sum of $£ 113.83$ per child. At a later stage, however, it deducts a flat $£ 131.63$ per child. In Table 3 we show the net effect of these two rather contradictory elements as a flat amount of $-£ 17.80$ per resident child

The five deprivation top-ups for children

An LA's costs in providing services for children also depend on the amount of local deprivation. The ODPM allow for this with five deprivation top-ups as follows.

- They allow £331.54 for all dependent children living in flats.

- They allow £2,559.58 for all resident children with a limiting long-term illness.

- They allow an extra $£ 476.10$ for all children dependent on a claimant of IS or IBJSA;

- They allow an extra £921.37 for all children living in one-adult households;

- They allow for the extra costs in LAs with a high density of population by taking the total population per hectare and multiplying it by £0.82; thus Aberdeen City has a density of 11.27 people per hectare and gets $£ 0.82(11.27)$ per child, that is $£ 9.24$ per child.

Table 3 shows each of these allowances in sums per child.

The foster cost adjustment

A LA's need to spend on children's PSS also depends on the cost of foster care. FSS allows for this by multiplying the total FSS obtained so far - that is the basic amount plus the five deprivation top-ups - by a foster cost adjustment which is a cost index. To calculate the 
index for each LA, the ODPM first find the value of a fixed component of 301.554 plus 221.521 times the proportion of children aged under 16 with specified birth locations minus 303.777 times the proportion of households with heads in any occupation where the head is in a routine or semi-routine occupation. Then the ODPM divide the resulting number by 50.8054, add the result of this division to 0.806 , and divide that result by 0.9523 .

The birth locations specified in this index cover all children born outside the UK, unless their head of household was born in the Republic of Ireland, the USA or the Old Commonwealth. They also cover all children born inside the UK, unless their head of household was born in the UK, the Republic of Ireland, the USA or the Old Commonwealth.

Table 4 begins with information about the two factors on which this index depends: the percentage of children with the specified countries of birth, and the percentage of heads of households in routine or semi-routine occupations. Table 4 then gives the value of the foster cost adjustment per child. As having a high percentage of people in routine or semi-routine occupations reduces the value of the adjustment, so its value is below average in LAs like East Ayrshire and Inverclyde which have above average percentages of such people. Incidentally, these two LAs actually have similar percentages, and so have similar indexes. But they get very different amounts per child from the index, because the index in Inverclyde is applied to a much higher total, as shown in the final column of Table 3.

\section{Area cost adjustments for children's PSS}

The final factor allowed for in FSS is an area cost adjustment (ACA). The ODPM (2004a, 68) says that ACAs 'reflect differences in the cost of providing social services across the country [England].' So, in high cost areas, the ODPM raise the FSS figures as determined so 
far by applying ACAs. For children's PSS, the ACAs range from $45.3 \%$ in the City of London and 25.0\% in Inner London boroughs to $0.8 \%$ in Merseyside and, of course, $0 \%$ for LAs which do not receive them. We compared wage levels (from Table A21 of NES 2000, 2001 and 2002) over 2000-02 in Scottish LAs with those in English LAs that get ACAs, and we found that only Aberdeenshire, Edinburgh and Glasgow would be likely to get ACAs; Table 4 shows our estimated per capita amounts for these LAs.

The total FSS for children's PSS

In essence, it is possible to sum all the components of Tables 3 and 4 to get the total FSS per child in each LA. However, the ODPM make some minute adjustments to scale the total FSS for children's services in England to a pre-determined figure called a control total. We scaled our Scottish figures by an identical amount, so some of the total FSS per child figures shown in Table 4 differ from the sum of the various FSS components by up to $£ 0.12$.

Scotland's average FSS per child is $£ 390.70$ which is $£ 53.79$, or $16.0 \%$, above England’s figure of £336.91. The main factors raising Scotland's needs are the number of children living in flats and the number in 1-adult homes; these respectively add $£ 58.38$ and $£ 18.15$ per child more in Scotland than in England. However, Scotland has fewer children in dense areas, fewer not born in the UK, and fewer ACAs. Although Scotland as a whole does better than England, the needs of its most needy area, Glasgow, at $£ 801.16$, are far below Tower Hamlets at $£ 1,238.63$; Tower Hamlets scores more on many factors and receives a generous ACA. Also, Scotland's least needy area, Orkney, has slightly lower needs than Wokingham.

Of course, the proportion of the total population accounted for by children varies between LAs, as shown in the sixth column of Table 4. So the FSS per head of total population, 
shown in the final column, is not proportional to the FSS per child. For example, the FSS per child is £296.37 in South Ayrshire and a similar £298.75 in West Lothian; but the former has a smaller percentage of children in its population, so its FSS per head is lower, at $£ 60.27$, compared to the latter’s $£ 72.82$. (Our total population figures came from GROS 2002, Table 1). Scotland’s average FSS per head is $£ 83.92$, which is $11.3 \%$ above England’s figure of $£ 75.41$. Scotland's percentage excess per head is less than its excess per child, because it has a slightly lower percentage of children in the population.

\section{The FSS sub-block for older people and its application to Scotland}

The sub-block for older people covers the provision of personal social services for people aged 65 and over. However, for the purposes of this block, FSS does not talk about all resident adults in this range but rather about each resident in a household plus each resident supported by the LA in residential or nursing care. The result of this definition is that FSS effectively overlooks about $1 \%$ of adults aged 65 or more. In this section, the word 'adult' covers only the older adults relevant for FSS. Tables 5, 6 and 7 show how needs per adult, as estimated by FSS, vary between LAs. The following vary between paragraphs indicate the factors involved: Appendix 2 gives our sources for Scottish LA data.

The basic sum per older adult

The FSS formula begins by allowing an LA a basic amount of £367.47 per adult. Later, however, it deducts a flat $£ 193.22$ and also a flat $£ 462.64$ per adult. In Table 5 we show the net effect of these three rather contradictory elements as a flat amount of -£288.39 per adult.

The two age top-ups 
The cost of providing older people's PSS in an LA depends on the age profile of the older people as well as on their number. FSS allows for this with the following two 'age top-ups':

- An age top-up for adults aged 75-84, allowing £343.87 for each.

- An age top-up for adults aged 85 or more, allowing £1,159.72 for each.

Table 5 shows the total age top-up per adult for each LA. The figures are relatively high in LAs like Eilean Siar where relatively more people aged 65 or above are actually 75 or more.

The six deprivation top-ups for older people

An LA's costs in providing services for older adults also depend on the amount of local deprivation. The ODPM allow for this with six deprivation top-ups as follows.

- They allow an extra $£ 252.73$ for all residents of pensionable age living in rented accommodation.

- They allow an extra $£ 365.00$ for all adults aged 65 or more with a limiting long-term illness.

- They allow an extra £508.98 for all older people who are, or whose partners are, on IS or IBJSA (this indicator actually covers people aged 60 or more).

- They allow an extra £305.12 for all pensioners living alone.

- They allow an extra £1,012.03 for all older people on attendance allowance or disability living allowance, here called people aged $65+$ on $A A / D L A$.

- They allow an extra £547.28 for all residents of pensionable age who are not part of a couple and not a head of household.

Tables 5 and 6 show the effects of each factor in sums per adult.

The low income index 
A further factor affecting LA service costs is low incomes, because LAs spend more in areas where people are less able to pay any charges that LAs might impose. This factor is allowed for by a low income index. For each LA, the index is calculated in three main steps, with no direct reference to incomes. The first step is to find the value of (a) a fixed amount of 0.483 , minus (b) 1.371 times the proportion of pensioners who are not in a couple and not head of a household, minus (c) 0.150 times the proportion of pensioners in rented accommodation (Appendix 1 gives the relevant sources). The second step is to divide the resulting figure by the ACA for the LA, which simply means that this low income adjustment is the only component of the FSS for this sub-block that does not benefit from the ACA made later. The third step is to subtract the resulting sum from 1 and divide the result by 0.6459 . Table 6 shows the index for each LA. A high index indicates a high need for help with low incomes.

The arithmetic used in calculating this index means that the LAs which benefit most are those with many renters and with few pensioners who are in couples or heads of a household. The results are occasionally surprising: for example, Westminster has more of a problem with low incomes than Glasgow, and Wokingham has more of a problem than Herefordshire. The index is allowed for in the FSS formulae by multiplying the sum of the basic amount, the two age top-ups and the six deprivation top-ups by the index. The effect on FSS per adult of allowing for low incomes in this way is also shown in Table 6.

\section{Population sparsity}

The older person's FSS also allows for sparsity, because people attending older people have further to travel in sparse areas. This factor is also allowed for by an index. For each LA, the index is calculated in three steps. The first step is to sum two components: (a) 2 multiplied by the population of census enumeration districts with 0.5 or fewer residents per 
hectare; and (b) the population of enumeration districts with more than 0.5 residents per hectare but not more than 4 . The second step is to multiply this sum by 0.0222 and then add the result to 0.9958 . The third step is to divide the resulting amount by 0.9958 . The index is allowed for by multiplying the sum arrived at after making the low income adjustment by the index. The effect on FSS per adult of allowing for sparsity in this way is shown in Table 7.

\section{Area cost adjustments for older people}

Finally, FSS allows for ACAs. For older people’s PSS, the ACAs range from $50.3 \%$ in the City of London and 28.0\% in Inner London boroughs to 0.8\% in Merseyside and 0\% for LAs which do not receive them. As noted above, we found that only Aberdeenshire, Edinburgh and Glasgow would be likely to get ACAs; Table 7 shows our estimates for these LAs.

\section{The total FSS for older people's PSS}

In essence, it is possible to sum all the components of Tables 5, 6 and 7 to get the total FSS per adult in each LA. However, the ODPM scale these sums very slightly to make the total FSS equal a pre-determined control total. We scaled our Scottish figures by an identical amount, so some of the total FSS per adult figures shown in Table 7 differ from the sum of the various FSS components by $£ 0.01$.

Scotland’s average FSS per older adult is $£ 806.68$ which is $£ 114.38$, or $16.5 \%$, above England’s figure of $£ 692.30$. The main reasons for Scotland’s higher amount are the number of people who rent homes, which adds $£ 45.21$ more in Scotland than England, the number on IS or IBJSA, which adds $£ 17.43$ more, the number on AA or DLA which adds $£ 30.19$ more, and the low income adjustment, which adds $£ 36.21$ more. On the other hand, Scotland has relatively fewer people aged 75-84 and 85 or over, and lower ACAs. 
Although Scotland as a whole does better than England, the $£ 1.110 .30$ needs of its most needy area, Glasgow, are way below Tower Hamlets at £1,594.31. Tower Hamlets scores more highly on the number on IS or IBJSA and on the low income adjustment, and it also receives a high ACA. However, Scotland's least needy area, Moray, has higher needs than both Herefordshire and Wokingham and, in fact, several other English LAs.

Of course, the proportion of the total population accounted for by older adults varies between LAs, as shown in the fifth column of Table 7. So the FSS per head of total population, shown in the final column, is not proportional to the FSS per adult. For example, the FSS per adult in Eilean Siar is $£ 889.14$, which is well below the $£ 908.89$ in West Lothian. But the former has a much greater percentage of older adults in its population, so its FSS per head is much higher, at $£ 176.86$ compared to the latter’s $£ 105.90$. Scotland’s average FSS per head is $£ 127.82$, which is $19.1 \%$ above England’s figure of £107.32. Scotland’s percentage excess per head is greater than its excess per older adult because it has a slightly higher percentage of older adults in the population.

\section{The FSS sub-block for younger adults and its application to Scotland}

The sub-block for younger adults covers the provision of personal social services for people aged 18-64. In this section, the word adult refers only to this group. Table 8 shows how needs per adult, as estimated by FSS, vary between LAs. The following paragraphs indicate the factors involved: Appendix 3 gives our sources for Scottish LA data.

The basic sum per younger adult 
The FSS formula begins by allowing an LA a basic amount of $£ 75.93$ for each resident adult. Later, however, it deducts a flat $£ 28.32$ per adult. In Table 8 we show the net effect of these two rather contradictory elements as a flat amount of $£ 47.61$ per adult.

The three deprivation top-ups for younger adults

An LA's costs in providing services for younger adults also depend on the amount of local deprivation. The ODPM allow for this with three deprivation top-ups as follows.

- They allow an extra £216.62 for all adult claimants of IS or IBJSA aged 18-64.

- They allow an extra £97.60 for all younger adults in households with no family. These households comprise: (a) households where there is just one adult; and (b) households, like those filled with unrelated students, where there is more than adult but where the adults come from more than one family and where none of the adults have dependent children living with them. The ODPM assume that the proportion of younger adults in such households equals the proportion of households that have no family.

- They allow an extra $£ 103.95$ for all younger adults estimated to be living in rented public sector flats; the ODPM assume that the proportion of younger adults living in such flats equals the proportion of households that live in them.

Table 8 shows the effects of each factor in sums per adult.

Area cost adjustments for younger adults

Finally, FSS allows for ACAs. The ACAs used for younger adults PSS are the same as those used for children's PSS. As noted above, we found that only Aberdeenshire, Edinburgh and Glasgow would be likely to get ACAs; Table 7 shows our estimated amounts for these LAs. 
In essence, it is possible to sum all the components of Table 8 to get the total FSS per younger adult in each LA. However, the ODPM scale these sums very slightly to make the total FSS equal a pre-determined control total. We scaled our Scottish figures by an identical amount, so some of the total FSS per adult figures shown in Table 8 differ from the sum of the various FSS components by $£ 0.01$.

Scotland’s average FSS per younger adult is $£ 123.84$ which is $£ 13.65$, or $12.4 \%$, above England’s figure of $£ 110.19$. The main reasons for Scotland's higher amount are the number of adults in public sector rented flats, which adds $£ 11.38$ more in Scotland than England, and the number on IS or IBJSA, which adds $£ 5.29$ more. However, Scotland has less ACAs.

Although Scotland as a whole does better than England, the $£ 180.12$ needs of its most needy area, Glasgow, are $24.0 \%$ below Tower Hamlets needs at £236.92; Tower Hamlets has more people in public sector rented flats, and it also receives a high ACA. However, Scotland's least needy area, Shetland, has 4.7\% higher needs than Wokingham.

Of course, the proportion of the population accounted for by younger adults varies between LAs, as shown in the final column of Table 8. So the FSS per head of total population, which is shown in the first column of Table 9, is not proportional to the FSS per adult that is shown in Table 8. For example, the FSS per adult in Aberdeen City is $£ 125.30$, which is below the $£ 130.26$ in West Dunbartonshire. But Aberdeen City has a higher percentage of younger adults in its population, so its FSS per head overall is higher, at £82.82, compared to West Dunbartonshire’s £80.49.

\section{Scotland and England compared}


The main aim of this paper is to compare how much Scottish LAs would be found to need to spend on PSS using the FSS formulae with the amounts that English LAs are found to need to spend. We have seen that Scotland has higher needs per child for children's PSS, higher needs per older adult for older people’s FSS, and higher per younger adult for younger adults’ PSS. In each case it also has higher needs per head of the population as a whole. Table 9 copies the needs per head for children's PSS from Table 4 and the needs per head for older people's PSS from Table 7. It then gives an overall total, and shows that Scotland's total needs are $£ 289.07$ per head, which is $15.3 \%$ above England’s figure of $£ 250.74$. Scotland’s FSS per head ranges from $£ 450.76$ in Glasgow to $£ 192.60$ in Orkney. The range in England is wider, running from $£ 600.11$ in Tower Hamlets to $£ 146.08$ in Wokingham.

As well as FSS figures, Table 9 gives the total 2004-05 social work spending needs per head for Scottish LAs, as assessed on the SE’s GAE formulae (figures from SE, 2003b). The total GAE per head is $£ 352.54$, which is $22.0 \%$ above the total FSS per head. Section II noted that comparing FSS figures and GAE figures is contentious, as FSS and GAE reflect different frameworks. Nevertheless, this gap calls for some comment.

A major reason for the gap is that FSS does not actually cover all PSS spending needs. In 2004-05, English LAs received specific grants for PSS that would take their PSS spending 13.6\% above their FSS (ODPM, 2004d, Key Table 1). In contrast, Scottish LAs received virtually no specific grants for social work (SE, 2003a). If Scotland's needs as estimated by FSS are raised by $13.6 \%$ to allow for specific grants, then its GAE is just $7.4 \%$ above the English assessment of its needs. Thus GAE appears to be a little more generous than FSS. 
Section I noted that both FSS and GAE claim to estimate relative spending needs. So, while any differences in the total level of Scottish needs for PSS implied by the two approaches might reflect disagreements about absolute need, one might expect FSS and GAE to give the various LAs similar relative needs. To explore this, Table 9 has a column to show the FSS per head of all Scottish LAs, as a proportion of the average Scottish FSS, and a column to show the GAE per head of all Scottish LAs, as a proportion of the average Scottish GAE.

The FSS figures run from 0.67 of the average in Orkney to 1.56 in Glasgow. The GAE figures run from 0.78 in East Dunbartonshire to 1.33 in Falkirk. There are some large differences, especially in the islands. For example, Eilean Siar would get $6 \%$ below average under FSS but gets 33\% more under GAE. Perhaps the islands face some problems which GAE addresses and FSS ignores. If so, then that would help explain why Scotland's total GAE is $7.4 \%$ above the English view of Scotland's needs. However, the islands have small populations, so they do not affect the overall Scotland figure much. If they were excluded, then GAE would exceed the English view of Scotland's needs by $6.9 \%$ instead of $7.4 \%$.

There are some big differences between relative FSS and relative GAE even for the mainland LAs. For example, Glasgow would get 56\% more than the average under FSS but gets only 21\% more under GAE. In contrast, Perth and Kinross would get $17 \%$ below average under FSS but gets $5 \%$ above average on GAE.

\section{Conclusions}

Scotland and England compared 
This paper examines the extent to which Scotland has higher per capita spending needs than England for PSS. It does so by applying the English FSS formula for assessing LA needs to Scottish LAs. FSS indicates that in 2004-05 Scotland needed 15.3\% more per head for PSS.

Elsewhere, we have applied FSS to Scotland for two other groups of LA services. In King et al 2004, we found that applying to Scotland the FSS formulae for LA spending needs on education in 2003-04 indicated that Scotland's needs per pupil were about 3\% above England's; however, because Scotland has slightly fewer pupils in relation to its overall population, its FSS per head is actually about 1\% below England’s. In King et al 2006, we find that applying to Scotland the FSS formulae for LA spending needs on other services suggests that Scotland's per capita needs were about 6.4\% above England's for environmental, protective and cultural services (EPCS), 8.1\% above for highway maintenance, and between $24.3 \%$ and $35.3 \%$ above for fire services.

Taking all these results together, and weighting each group of services by its contribution to total FSS, our research indicates that Scotland's per capita needs for all LA services (except police) are between $5.5 \%$ and $6.0 \%$ above England's. ${ }^{3}$ Such a gap is way below the $25 \%$ by which per capita spending on public services in Scotland exceeds England's. It is true that the LA services we have explored omit almost half public services, but for the true overall figure to be $25 \%$, Scotland's per capita needs on the others, such as health, would have to exceed England's by a very improbable amount of nearly 50\%.

We must stress that the comparisons of need in Scotland and England just noted are only as robust as FSS is itself at indicating relative need. It was to throw some light on this issue that

\footnotetext{
${ }^{3}$ We cannot be more precise because we were unable to get an exact Scottish FSS for fire services.
} 
we contrasted the estimates of relative needs for Scottish LAs that FSS would yield if it were used in Scotland with the estimates of relative need that GAE does yield.

Table 9 suggests that FSS may underestimate relative PSS needs in rural areas, and overestimate them in urban areas. For example, Glasgow would get 56\% more than the Scottish average under FSS but gets only 21\% more under GAE; while Highland would get 21\% less than the Scottish average under FSS but gets only 3\% less under GAE.

We found similar results for environmental, protective and cultural services (EPCS) and highway maintenance. For example, under FSS, Highland would be allowed 13\% less than the Scottish average for EPCS and 28\% more for highway maintenance; but under GAE it is allowed 10\% more than the average for EPCS and 113\% more for roads. Also, under FSS, Glasgow would be allowed 42\% more than the Scottish average for EPCS and 9\% less for highway maintenance; but under GAE it is allowed 19\% more than the average for EPCS and $44 \%$ less for roads.

In contrast, our paper on local education services (King et al 2004) did not reveal any clear tendency for FSS to favour urban areas. However, if FSS does underestimate total needs in rural areas, and overestimate them in urban areas, then it will tend to underestimate needs in Scotland as a whole, so Scotland's relative needs may be higher than FSS suggests. However, it is possible that FSS measures relative needs for these services well, while GAE underestimates needs in urban areas and overestimate them in rural areas.

\section{General conclusions}


In addition to the above results, three more general conclusions can be drawn. First, we have argued that the differences in the way in which FSS and GAE assess relative need may indicate either that at least one of them is seriously flawed; possibly both are flawed. The fact that one, or perhaps both, may be flawed forms a strong case for reviewing them both, and here there must be a case for Holyrood and Westminster seeing what they can learn from each other about needs assessment.

Secondly, because FSS may be flawed, its indication that Scotland's per capita needs are around 6\% above England's may be a significant understatement. Even so, many people will doubt whether Scotland's needs exceed England's to the same extent that its per capita public spending exceeds England's. So there may well be a case for replacing the current Barnett formula by a Barnett Mark II formula which assesses the needs for public spending as a whole across the two countries. There would certainly be a case for doing this if, in future, under a scheme of significant financial devolution, the Scottish Executive raised most of its revenue from taxes and received Westminster funds only to cover higher needs.

Finally, while the case for devising a Barnett Mark II formula seems strong, Barnett Mark II will be very hard to devise. It will be harder than assessing LA spending needs, because it will have to cover devolved central government services such as health and higher education as well as LA services. Also, for political reasons, it will surely have to be accepted as fair in both Scotland and England; yet there are several results in this paper which suggest that Scotland and England may hold very different views about needs, so satisfying both countries may prove problematic. However, we hope that the work in this paper and our two others, along with the many data sources that we have identified, will help anyone who does try to devise such a formula. 


\section{Appendix 1: data and sources for services for children}

Note: the precise ODPM description of the data needed for each factor is given in italics.

Resident children aged 0-17, 2002. We used Scottish LA data from GROS (2002, Table 2).

Dependent children living in flats, using the 1991 Census. The ODPM (2004a, p.64) say that the indicator is the percentage of dependent children aged under 16 living in flats of various types; however, the data that they actually use for English FSS figures concern all children aged under 18, and we used the same for Scotland. We applied the 1991 proportion of children living in flats given in the Scottish 1991 Census (GROS 1993, Table 79) to the number of resident children in 2002.

Resident children aged under 18 with a limiting long-term illness, using the 1991 Census. GROS (1993, Tables 2, 12 and 13) gives the total number of residents under 18, and also the numbers with limiting long-term illnesses living in households and living in communal establishments. We applied the 1991 proportion with a limiting long-term illness to the number of resident children in 2002.

Children aged under 18 depending on claimants of IS or IBJSA, averaged over 2000 to 2002. For dependents of IS claimants, we obtained Scottish LA data for 2000 from National Statistics (2005), and for 2001 and 2002 from DWP (2005a and 2005b). We were able to obtain data for dependents of IBJSA claimants only for 2001 (from DWP, 2005c): we raised these figures by $4.14 \%$ because the average number of claimants in Great Britain over 200002 was 4.14\% above the 2001 number (from National Statistics 2004, Table 10.6). We applied the average proportions for 2000-2002 to the number of resident children in 2002. 
Proportion of dependent children aged under 18 living in one-adult households, using the 1991 Census. Our Scottish LA proportions were derived from figures in GROS (1993, Table 66) for the number of children and the number in one adult households.

Population per hectare, using 2002 LA populations and 1991 LA sizes from the 1991 Census. We obtained 2002 Scottish LA population data from GROS (2002); but for LA sizes we used 2002 Scottish LA data from SCROL (2005, Table UV02) instead of the 1991 Census, because the present Scottish LAs did not exist in 1991.

Proportion of children under 16 with specified birth locations (see main text for location details) using the 1991 Census. We used data from GROS (1993, Tables 32 and 50).

Proportion of households with an occupied head whose head is in a routine or semi-routine occupation, averaged over 2001 to 2003. The best data we found for Scottish LAs were 2001 data from SCROL (2005, Table CAS045).

\section{Appendix 2: data and sources for services for older people}

The number of adult residents aged 65 or over in households plus those supported in residential or nursing care by the LA, 2002. We estimated Scottish LA data using the same circuitous method used by the ODPM. We began with the resident population aged 65 or over in 2002 (from GROS 2002, Table 2). To estimate the household population in 2002, we scaled this downwards by the proportion of older people living in households given by the 1991 Census (GROS, 1993, Tables 2 and 35). To estimate the number of supported residents, we used LA data for 2004 given by SE (2004, Annex A) for occupied registered 
places in Local Authority Care Homes for Older People (which include what prior to 2002 were called nursing homes); we then scaled these figures in line with the small change in total occupied places between 2002 and 2004 taken from the same source (Table 2).

Household and supported residents aged 75-84, 2002, and Household and supported residents aged 85 or above, 2002. We estimated Scottish LA figures for household residents in these age ranges using the sources and methods outlined in the preceding paragraph. We estimated LA figures for supported residents in each age range by apportioning the total number of supported residents in each LA in proportion to the total number of long stay residents in different age ranges in 1999, as given by SE (2001, Table 2.2).

Household residents of pensionable age living in rented accommodation using the 1991 Census. We used GROS (1993, Table 67) for Scottish LA data for the total number of household residents of pensionable age and the number in rented accommodation in 1991. We applied the resulting proportion for each LA to the number of its adults in 2002.

Residents aged 65 or over with a limiting long-term illness using the 1991 Census. We used GROS (1993, Tables 2, 12 and 13) for Scottish LA 1991 data for the total number of adults aged 65 or more and the numbers with limiting long-term illnesses living in households and in communal establishments. For each LA, we applied the resulting proportions of those with a limiting long-term illness to the number of its adults in 2002.

The number of residents who are, or whose partner is, aged 60 or over and receives IS or IBJSA, as a proportion of adults aged 65, averaged over 2000-02. For IS, we obtained Scottish LA data for 2000 from National Statistics (2005), and for 2001 and 2002 from DWP 
(2005a and 2005b). For IBJSA, DWP (2002b, Table 7.2) says that 924,000 people claimed JSA in 2002 in Great Britain, and that $70.4 \%$ of them were on IBJSA, that is 650,496 . It also says that 9,000 people aged 60 or over claimed JSA in 2002 in Great Britain, and that 27.1\% of them were on IBJSA, that is 2,439. So we assumed that 2,439/650,496 of all JSA beneficiaries are 60 or over. The same source also says (Table 6.3) that Scotland has as IBJSA beneficiaries 75,000 claimants plus 9,000 partners, that is 84,000 people. So we infer that in Scotland 2,439/650,496 of 84,000 - that is 315 - people are IBJSA claimants or partners of claimants aged 60 or more. We raised this number by $10.20 \%$ to 347 because National Statistics (2004, Table 10.6) showed that the average number of claimants in Great Britain over 2000-02 was $10.20 \%$ above the 2002 number; and we split these 347 people by LA in proportion to the total claiming IBJSA in 2001 (from DWP, 2005c).

Household residents of pensionable age who live alone using the 1991 Census. We used GROS (1993, Table 67) for Scottish LA data for the total number of household residents of pensionable age and the number who lived alone. We applied the resulting proportion for each LA to the number of its adults in 2002.

Residents aged 65 or over on AA or high or middle DLA averaged over 2001 to 2003. For AA we began with the 2004 Scottish LA numbers from DWP (2004a, Table AA12) and took them all to be 65 or over. For DLA we began with the 2004 Scottish LA numbers from DWP (2004b, Table DLA12) and scaled them down in line with the percentage of claimants in Great Britain as a whole who were 65 or over (from Table DLA2); and we scaled these resulting figures down in line with the percentage of Great Britain claimants on high or middle living care allowances (from Table DLA1). We then scaled all our 2004 AA and DLA numbers in line with the changes between the average for 2001 to 2003 and the figure 
for 2004 in the total numbers of claimants in Great Britain (from Tables AA1 and DLA1). We then found that if we used analogous data and methods for England, we reached a slightly different total from that used by the ODPM, so we scaled our LA figures in proportion to this discrepancy.

Household residents of pensionable age who are not in a couple and not head of household, using the 1991 Census. We used GROS (1993, Tables 47 and 53) for Scottish LA data for the total number of household residents of pensionable age and the number who were not in a couple and not head of a household. We applied the resulting proportion for each LA to the number of its adults in 2002.

Resident population in sparse enumeration districts, using the 1991 Census. Owing to changes in Scottish LA boundaries since 1991, we used data for census area statistic wards from the 2001 Census (SCROL, 2005, Table UV02). The figures in column (7) of Table C show the percentage of people living in wards with less than or equal to 4 residents per hectare, but there is a double weight for those living in wards with less than or equal to 0.5 residents per hectare.

\section{Appendix 3: data and sources for services for younger adults}

Resident adults aged 18 to 64, 2002. We used Scottish LA data from GROS (2002, Table 2).

Claimants of IS or IBJSA, aged 18-64 inclusive, averaged over 2000 to 2002. For IS claimants, we obtained Scottish LA data for 2000 from National Statistics (2005), and for 2001 and 2002 from DWP (2005a and 2005b). However, these statistics divided claimants into those aged 18-59 and those aged 60 or more. For each LA we added to the former a 
uniform fraction of the latter, to estimate the numbers aged 18-64; we derived our fractions from data in DWP (2002a, Table 2.1). We were able to obtain data for IBJSA claimants only for 2001 (from DWP 2005c) and assumed all claimants were aged 18-64. We raised these figures by $4.14 \%$ because National Statistics (2004, Table 10.6) showed that the average number of claimants in Great Britain over 2000-02 was 4.14\% higher than the 2001 number.

The proportion of households with no family, using the 1991 Census. We used data from GROS (1993, Table 87) to estimate Scottish LA data for the number of households and the number with no family; both sets of figures were based on a $10 \%$ sample of households.

The proportion of households living in public sector rented flat, using the 1991 Census. We used data from GROS (1993, Table 78) to estimate Scottish LA data for the number of households and the number of households living in public sector rented flats; strictly, this is households living in purpose-built flats in residential buildings rented from a local authority, new town or housing association.

\section{References}

DWP, 2002a, Department for Work and Pensions Income Support: Quarterly Statistical Enquiry: August 2002, http://www.dwp.gov.uk/asd/asd1/qse/aug2002/is_aug2002_pub.pdf

DWP, 2002b, Department for Work and Pensions Jobseeker's Allowance: Quarterly Statistical Enquiry August 2002, http://www.dwp.gov.uk/asd/asd1/jsa/jsa_qse_aug02/jsa_aug2002_pub.pdf 
DWP, 2004a, Department for Work and Pensions Attendance Allowance: Quarterly Statistics May 2004, http://www.dwp.gov.uk/asd/asd1/aa/aa_quarterly_statistics_may04.asp

DWP, 2004b, Department for Work and Pensions, Disability Allowance: Quarterly Statistics May 2004, http://www.dwp.gov.uk/asd/asd1/dla/dla_quarterly_statistics_may04.asp

DWP, 2005a, Department for Work and Pensions, Income Support at August 2001 by Local Authorities/Unitary Authorities in Scotland, http://www.dwp.gov.uk/asd/asd1/neighbourhood/2001/is2001_Scotland.xls

DWP, 2005b, Department for Work and Pensions, Income Support at August 2002 by Local Authorities/Unitary Authorities in Scotland, http://www.dwp.gov.uk/asd/asd1/neighbourhood/2002/is2002_Scotland.xls

DWP, 2005c, Department for Work and Pensions, Jobseeker's Allowance at August 2002 by Local Authorities/Unitary Authorities in Scotland, http://www.dwp.gov.uk/asd/asd1/neighbourhood/2001/jsa2001_all_Scotland.xls

GROS, 1993, General Register Office for Scotland, 1991 Census, Edinburgh, HMSO (published in numerous regional volumes.)

GROS, 2002, General Register Office for Scotland, Tables of Mid-2002 Population Estimates, Scotland, http://www.gro-scotland.gov.uk/statistics/library/poptest/02-mid-yearest/02-mid-year-tables.html 
HM Treasury, 2004, Public Expenditure: Statistical Analyses 2004, http://www.hmtreasury.gov.uk/media/D27/4A/pesa04_complete_190404.pdf

King, D., M. Pashley and R. Ball, 2004, ‘An English assessment of Scotland’s education spending needs', Fiscal Studies 25:4, December, 439-66.

King, D., M. Pashley and R. Ball, 2006, ‘The Environmental Spending Needs of Scotland’s Local Authorities', Local Government Studies (forthcoming).

National Statistics, 2004, Annual Abstract of Statistics 2004, London: The Stationery Office.

National Statistics, 2005, Neighbourhood Statistics, http://neighbourhood.statistics.gov.uk (using detailed information by subject on economic deprivation).

NES, 2000, New Earnings Survey 2000 Part E: Analyses by Region, County and Small Areas, London: The Stationery Office.

NES, 2001, New Earnings Survey 2001 http://www.statistics.gov.uk/downloads/theme_labour/NES2001_GB/NES2001_Streamlined _analyses.pdf

NES, 2002, New Earnings Survey 2002

http://www.statistics.gov.uk/downloads/theme_labour/NES2002_GB/NES2002_Streamlined _analyses.pdf 
ODPM, 2002, Office of the Deputy Prime Minister, Statement on Local Government Finance in England, 2003-04, 5 December 2002.

ODPM, 2004a, Office of the Deputy Prime Minister, The Local Government Finance Report (England) 2004/2005, London: The Stationery Office.

ODPM, 2004b, Office of the Deputy Prime Minister, Local Government Finance 2004/05 RSG Settlement Individual Local Authority Tables, http://www.local.odpm.gov.uk/finance/0405/tabs045.htm

ODPM, 2004c, Office of the Deputy Prime Minister, Local Government Finance Settlement 2005/06 http://www.local.odpm.gov.uk/finance/0506/grant.htm (under Formula Spending Shares by Sub-block).

ODPM, 2004d, Office of the Deputy Prime Minister, Parliamentary Pack http://www.local.odpm.gov.uk/finance/0405/keytabs/keytab1.xls

ODPM, 2006, A Guide to the Local Government Finance Settlement, http://www.local.odpm.gov.uk/finance/0607/simpguid.pdf

SE, 2000, Scottish Executive Grant Aided Expenditure 2001-02(The Green book) (supplied to us by the Executive.

SE, 2001, Scottish Executive Older People in Scotland: Results from the First Year of the Scottish Household Survey, http://www.scotland.gov.uk/cru/kd01/red/oldshs-05.asp 
SE, 2003a, Scottish Executive Local Government Finance and Performance (supplied to us by the Executive).

SE, 2003b, Scottish Executive Summary of GAE Assessments (2004-2005) by Service (supplied to us by the Executive).

SE, 2004, Scottish Executive Statistics Release: Care Homes, Scotland, March 2004, http://www.scotland.gov.uk/stats/bulletins/00367-07.asp

Scottish Parliament, 2002, An Introduction to Local Government Finance, Scottish Parliament Information Centre Devolved Area Series 99/03.

SCROL, 2005, Scotland’s Census Results OnLine Scrol Analyser, http://www.scrol.gov.uk/scrol/common/home.jsp

Twigger, R., 1998, The Barnett Formula, House of Commons Research Paper 98/8. http://www.parliament.uk/commons/lib/research/rp98/rp98008.pdf\#search=\%22twigger\%20house\%20of\%20commons\%20barnett\%20formula\%2098\% $2 \mathrm{~F} 8 \% 22$ 
Added at proof stage:

Mackay RR, Williams J

Thinking about need: Public spending on the regions

Regional Studies 39 (6): 815-828 AUG 2005

Kay A, Bristow G, McGovern M, Pickernell D

Fair division or fair dinkum? Australian lessons for intergovernmental fiscal relations in the United Kingdom

Environment and Planning C-Government And POLICY 23 (2): 247-261 APR 2005

McLean I, McMillan A

The distribution of public expenditure across the UK regions

Fiscal Studies 24 (1): 45-71 MAR 2003

Midwinter A

Financing devolution in practice: The Barnett formula and the Scottish budget, 1999-2003

Public Money \& Management 24 (3): 137-144 JUN 2004 
Table 1 The FSS factors for the three sub-blocks of FSS for PSS, England, 2004-05

\begin{tabular}{|c|c|c|c|}
\hline FSS factors & $\begin{array}{c}\text { Children } \\
(30.1 \% \text { of total } F S S)\end{array}$ & $\begin{array}{c}\text { Older people } \\
(42.8 \% \text { of total FSS) }\end{array}$ & \begin{tabular}{|c|} 
Younger adults \\
(27.1\% of total FSS) \\
\end{tabular} \\
\hline $\begin{array}{l}\text { Age group } \\
\text { Accommodation }\end{array}$ & $\begin{array}{l}\text { Residents aged 0-17 } \\
\% \text { who live in flats }\end{array}$ & $\begin{array}{l}\text { Residents aged } 64+ \\
\% \text { who rent household } \\
\text { accommodation }\end{array}$ & $\begin{array}{l}\text { Residents aged 18-64 } \\
\text { \% who rent public } \\
\text { sector flats }\end{array}$ \\
\hline Benefits & $\begin{array}{l}\% \text { with parents on } \\
\text { specified state benefits }\end{array}$ & $\begin{array}{l}\% \text { on specified state } \\
\text { benefits }\end{array}$ & $\begin{array}{l}\% \text { on specified state } \\
\text { benefits }\end{array}$ \\
\hline Health & $\%$ with long-term illness & $\%$ with long-term illness & - \\
\hline Households & $\%$ from 1 -adult homes & $\begin{array}{l}\text { \% living alone, or not in } \\
\text { a couple, or not head of a } \\
\text { household }\end{array}$ & $\%$ with no family \\
\hline Labour costs & Relative LA costs & Relative LA costs & Relative LA costs \\
\hline Locality & $\begin{array}{l}\% \text { in densely populated } \\
\text { areas }\end{array}$ & $\begin{array}{l}\% \text { in sparsely populated } \\
\text { areas }\end{array}$ & \\
\hline Other factors & $\begin{array}{l}\% \text { of children with certain } \\
\text { countries of birth and \% } \\
\text { with parents on routine or } \\
\text { semi-routine occupations }\end{array}$ & $\begin{array}{l}\% \text { of older people aged } \\
75-84 \text { and } \% \text { of older } \\
\text { people aged } 85+\end{array}$ & - \\
\hline
\end{tabular}

Source: ODPM (2004a).

Table 2 The main components of GAE for social work, Scotland, 2004-05

\section{\% Component of Social Work GAE}

43.3 Services for the home-based elderly, and residential accommodation for the elderly

16.3 People with disabilities

8.6 Administration \& casework

7.6 Community \& residential care for children

4.4 Personal \& nursing care for older people

4.0 Other social work services

3.5 Care home fees

2.0 Day care for children

1.2 Carers service and respite care

9.1 Other

100.0 Total

\section{Indicators where specified}

Elderly in various age groups; mortality rates; those living alone, with limiting long-term illnesses, or on IS

Population 16-64

Mainly proportional to other components

Under 16s; those in households receiving IS or IBJSA; those with lone parents

(Not specified)

Total population

(Not specified)

Under 5s; those with 'stressed' families

Same as first two items on this table

Source: SE (2000, Tables D-G, and 2003b). 
Table 3 FSS for Children's Social Services, 2004-05: Part A

\begin{tabular}{|c|c|c|c|c|c|c|c|}
\hline & $\begin{array}{c}\text { Basic } \\
\text { amount ch } \\
\text { £ per child } \mathrm{E}\end{array}$ & $\begin{array}{r}\text { Sum for } \\
\text { hildren in } \\
\text { flats } \\
\text { per child }\end{array}$ & $\begin{array}{l}\text { Sum for } \\
\text { long-term } \\
\text { ill children } \\
\text { E per child }\end{array}$ & $\begin{array}{r}\text { Sum for } \\
\text { IS/IBJSA } \\
\text { dependants } \\
\text { \& per child }\end{array}$ & $\begin{array}{r}\text { Sum for } \\
\text { children in 1- } \\
\text { adult homes } \\
\text { E per child }\end{array}$ & $\begin{array}{r}\text { Sum for } \\
\text { dense } \\
\text { population } \\
\text { £ per child }\end{array}$ & $\begin{array}{r}\text { Total of } \\
\text { factors on } \\
\text { this table } \\
\text { \& per child }\end{array}$ \\
\hline England & -17.80 & 29.79 & 60.13 & 92.35 & 121.78 & 15.93 & 302.18 \\
\hline Tower Hamlets & -17.80 & 277.49 & 80.95 & 276.40 & 166.80 & 85.92 & 869.76 \\
\hline Westminster & -17.80 & 270.79 & 72.62 & 178.04 & 206.55 & 72.53 & 782.73 \\
\hline Liverpool & -17.80 & 26.30 & 83.80 & 200.42 & 229.08 & 32.09 & 553.89 \\
\hline Leicester & -17.80 & 18.84 & 65.56 & 139.03 & 164.02 & 31.72 & 401.37 \\
\hline Herefordshire & -17.80 & 19.75 & 48.40 & 56.58 & 92.24 & 0.66 & 199.85 \\
\hline Wokingham & -17.80 & 7.00 & 41.31 & 22.13 & 54.37 & 6.93 & 113.95 \\
\hline Scotland & -17.80 & 88.17 & 62.84 & 93.37 & 139.93 & 6.44 & 372.95 \\
\hline Aberdeen City & -17.80 & 108.75 & 71.12 & 77.98 & 138.78 & 9.24 & 388.07 \\
\hline Aberdeenshire & -17.80 & 21.53 & 50.09 & 39.35 & 65.04 & 0.30 & 158.50 \\
\hline Angus & -17.80 & 64.55 & 52.71 & 69.55 & 107.79 & 0.41 & 277.20 \\
\hline Argyll \& Bute & -17.80 & 92.35 & 61.24 & 60.24 & 129.92 & 0.11 & 326.05 \\
\hline Clackmannanshire & -17.80 & 68.43 & 57.83 & 99.92 & 130.72 & 2.48 & 341.58 \\
\hline Dumfries \& G’way & -17.80 & 37.81 & 56.79 & 68.02 & 100.58 & 0.19 & 245.59 \\
\hline Dundee City & -17.80 & 149.56 & 71.44 & 131.66 & 224.35 & 19.76 & 578.98 \\
\hline E. Ayrshire & -17.80 & 56.98 & 68.06 & 109.56 & 139.53 & 0.78 & 357.11 \\
\hline E. Dunbartonshire & -17.80 & 77.76 & 55.50 & 42.31 & 118.26 & 5.04 & 281.07 \\
\hline E. Lothian & -17.80 & 55.07 & 57.06 & 59.11 & 107.20 & 1.10 & 261.73 \\
\hline E. Renfrewshire & -17.80 & 95.65 & 57.01 & 42.54 & 129.42 & 4.23 & 311.04 \\
\hline Edinburgh, City of & -17.80 & 144.69 & 63.58 & 90.49 & 166.64 & 13.93 & 461.53 \\
\hline Eilean Siar & -17.80 & 6.57 & 32.24 & 55.49 & 64.91 & 0.07 & 141.48 \\
\hline Falkirk & -17.80 & 64.14 & 64.03 & 84.30 & 131.03 & 4.01 & 329.72 \\
\hline Fife & -17.80 & 64.54 & 63.90 & 84.82 & 133.81 & 2.17 & 331.43 \\
\hline Glasgow, City of & -17.80 & 224.31 & 86.55 & 187.86 & 250.70 & 26.98 & 758.59 \\
\hline Highland & -17.80 & 19.15 & 49.81 & 70.82 & 105.46 & 0.07 & 227.52 \\
\hline Inverclyde & -17.80 & 146.77 & 74.33 & 117.31 & 174.67 & 4.27 & 499.56 \\
\hline Midlothian & -17.80 & 39.22 & 59.29 & 78.10 & 113.99 & 1.87 & 274.67 \\
\hline Moray & -17.80 & 19.41 & 54.82 & 54.73 & 88.21 & 0.32 & 199.68 \\
\hline N. Ayrshire & -17.80 & 43.78 & 66.59 & 119.16 & 158.29 & 1.26 & 371.28 \\
\hline N. Lanarkshire & -17.80 & 97.28 & 64.83 & 111.37 & 136.95 & 5.61 & 398.24 \\
\hline Orkney Islands & -17.80 & 11.35 & 34.32 & 32.77 & 73.38 & 0.16 & 134.19 \\
\hline Perth \& Kinross & -17.80 & 64.04 & 59.36 & 51.13 & 105.48 & 0.21 & 262.43 \\
\hline Renfrewshire & -17.80 & 95.65 & 57.01 & 101.13 & 129.42 & 5.40 & 370.81 \\
\hline Scottish Borders & -17.80 & 50.08 & 51.89 & 51.44 & 92.00 & 0.19 & 227.79 \\
\hline Shetland Islands & -17.80 & 9.69 & 42.23 & 32.57 & 73.60 & 0.12 & 140.40 \\
\hline S. Ayrshire & -17.80 & 54.43 & 56.39 & 80.09 & 111.34 & 0.75 & 285.20 \\
\hline S. Lanarkshire & -17.80 & 46.25 & 55.05 & 88.85 & 114.07 & 1.40 & 287.82 \\
\hline Stirling & -17.80 & 62.06 & 58.27 & 63.17 & 120.43 & 0.32 & 286.45 \\
\hline W. Dunbartonshire & -17.80 & 92.35 & 61.24 & 132.99 & 129.92 & 4.79 & 403.48 \\
\hline W. Lothian & -17.80 & 41.21 & 63.61 & 78.79 & 123.02 & 3.07 & 291.91 \\
\hline
\end{tabular}


Table 4 FSS for Children's Social Services, 2004-05: Part B

\begin{tabular}{|c|c|c|c|c|c|c|c|}
\hline & $\begin{array}{r}\% \text { of } \\
\text { children } \\
\text { not born in } \\
\text { UK etc. } \\
\end{array}$ & $\begin{array}{r}\text { \% of house- } \\
\text { hold heads in } \\
\text { routine etc. } \\
\text { occupations } \\
\end{array}$ & $\begin{array}{r}\text { Foster } \\
\text { cost } \\
\text { adjustment } \\
\text { £ per child } \\
\end{array}$ & $\begin{array}{r}\text { Sum } \\
\text { for } \\
\text { ACA } \\
\text { \& per child } \\
\end{array}$ & $\begin{array}{r}\text { FSS } \\
\text { (after } \\
\text { scaling) } \\
\text { E per child } \\
\end{array}$ & $\begin{array}{r}\text { Children } \\
\text { as \% of } \\
\text { total } \\
\text { population } \\
\end{array}$ & $\begin{array}{r}\text { FSS } \\
\text { (after } \\
\text { scaling) } \\
\text { £ per head } \\
\end{array}$ \\
\hline England & 11.96 & 21.43 & 15.39 & 19.38 & 336.91 & 22.38 & 75.41 \\
\hline Tower Hamlets & 57.44 & 17.27 & 121.00 & 247.99 & $1,238.63$ & 24.27 & 300.62 \\
\hline Westminster & 49.76 & 11.22 & 109.73 & 223.38 & $1,115.73$ & 14.42 & 160.89 \\
\hline Liverpool & 4.03 & 29.19 & 10.47 & 4.40 & 568.70 & 22.28 & 126.69 \\
\hline Leicester & 37.32 & 28.45 & 31.32 & 0.00 & 432.65 & 24.38 & 105.50 \\
\hline Herefordshire & 3.82 & 24.28 & 6.03 & 0.00 & 205.85 & 21.59 & 44.45 \\
\hline Wokingham & 10.11 & 8.70 & 8.87 & 15.13 & 137.93 & 23.18 & 31.97 \\
\hline Scotland & 4.14 & 22.32 & 13.36 & 4.43 & 390.70 & 21.48 & 83.92 \\
\hline Aberdeen City & 6.14 & 21.66 & 15.66 & 0.00 & 403.69 & 18.43 & 74.41 \\
\hline Aberdeenshire & 3.89 & 21.68 & 5.77 & 12.48 & 176.74 & 23.45 & 41.44 \\
\hline Angus & 3.67 & 23.23 & 8.97 & 0.00 & 286.14 & 21.32 & 61.00 \\
\hline Argyll \& Bute & 3.61 & 19.44 & 13.45 & 0.00 & 339.46 & 20.85 & 70.77 \\
\hline Clackmannanshire & 3.68 & 27.12 & 7.93 & 0.00 & 349.47 & 23.25 & 81.24 \\
\hline Dumfries \& G’way & 2.35 & 25.63 & 6.00 & 0.00 & 251.56 & 21.03 & 52.91 \\
\hline Dundee City & 5.49 & 24.52 & 18.79 & 0.00 & 597.71 & 20.03 & 119.72 \\
\hline E. Ayrshire & 2.12 & 26.43 & 7.90 & 0.00 & 364.98 & 22.22 & 81.10 \\
\hline E. Dunbartonshire & 4.34 & 13.14 & 16.13 & 0.00 & 297.17 & 22.83 & 67.83 \\
\hline E. Lothian & 3.10 & 21.66 & 9.19 & 0.00 & 270.90 & 23.16 & 62.74 \\
\hline E. Renfrewshire & 3.76 & 12.35 & 18.11 & 0.00 & 329.13 & 24.02 & 79.04 \\
\hline Edinburgh, City of & 7.71 & 15.62 & 26.46 & 32.35 & 520.29 & 18.25 & 94.97 \\
\hline Eilean Siar & 2.51 & 23.87 & 4.08 & 0.00 & 145.55 & 21.24 & 30.91 \\
\hline Falkirk & 2.52 & 24.37 & 9.13 & 0.00 & 338.82 & 21.79 & 73.84 \\
\hline Fife & 3.89 & 24.91 & 9.54 & 0.00 & 340.94 & 21.92 & 74.73 \\
\hline Glasgow, City of & 6.62 & 22 & 29.96 & 12.70 & 801.16 & 20.48 & 164.09 \\
\hline Highland & 3.11 & 23.22 & 7.15 & 0.00 & 234.64 & 21.92 & 51.42 \\
\hline Inverclyde & 2.15 & 27.09 & 10.31 & 0.00 & 509.82 & 21.86 & 111.45 \\
\hline Midlothian & 2.98 & 24.41 & 7.80 & 0.00 & 282.44 & 23.28 & 65.76 \\
\hline Moray & 4.67 & 23.41 & 6.72 & 0.00 & 206.39 & 22.40 & 46.24 \\
\hline N. Ayrshire & 2.55 & 24.55 & 10.14 & 0.00 & 381.38 & 22.47 & 85.70 \\
\hline N. Lanarkshire & 2.14 & 26.04 & 9.20 & 0.00 & 407.40 & 22.98 & 93.61 \\
\hline Orkney Islands & 2.32 & 23.23 & 4.03 & 0.00 & 138.21 & 22.33 & 30.86 \\
\hline Perth \& Kinross & 3.96 & 20.10 & 10.57 & 0.00 & 272.97 & 21.24 & 57.99 \\
\hline Renfrewshire & 3.76 & 22.34 & 12.84 & 0.00 & 383.61 & 21.79 & 83.58 \\
\hline Scottish Borders & 2.93 & 24.38 & 6.46 & 0.00 & 234.23 & 21.11 & 49.46 \\
\hline Shetland Islands & 2.35 & 26.63 & 3.10 & 0.00 & 143.49 & 24.25 & 34.80 \\
\hline S. Ayrshire & 3.02 & 19.84 & 11.20 & 0.00 & 296.37 & 20.34 & 60.27 \\
\hline S. Lanarkshire & 2.60 & 21.98 & 9.64 & 0.00 & 297.44 & 22.17 & 65.93 \\
\hline Stirling & 3.72 & 17.94 & 12.88 & 0.00 & 299.31 & 21.82 & 65.31 \\
\hline W. Dunbartonshire & 3.61 & 25.98 & 10.41 & 0.00 & 413.84 & 22.35 & 92.49 \\
\hline W. Lothian & 3.57 & 26.89 & 6.87 & 0.00 & 298.75 & 24.37 & 72.82 \\
\hline
\end{tabular}


Table 5 FSS for Older People's Social Services, 2004-05: Part A

\begin{tabular}{|c|c|c|c|c|c|c|}
\hline & $\begin{array}{r}\text { Basic } \\
\text { amount } £ \\
\text { per adult }\end{array}$ & $\begin{array}{r}\text { Age top-up } \\
\text { for adults } \\
75-84 \\
\text { E per adult }\end{array}$ & $\begin{array}{r}\text { Age top-up } \\
\text { for adults } \\
85+ \\
\text { E per adult }\end{array}$ & $\begin{array}{r}\text { Sum for } \\
\text { renting } \\
\text { pensioners } \\
\text { E per adult }\end{array}$ & $\begin{array}{r}\text { Sum for } \\
\text { long-term } \\
\text { ill adults } \\
\text { E per adult }\end{array}$ & $\begin{array}{r}\text { Total of } \\
\text { factors on } \\
\text { this table } \\
\text { E per adult }\end{array}$ \\
\hline England & -288.39 & 121.15 & 126.06 & 91.53 & 151.87 & 202.22 \\
\hline Tower Hamlets & -288.39 & 117.02 & 108.90 & 212.42 & 160.38 & 310.33 \\
\hline Westminster & -288.39 & 118.70 & 140.91 & 172.60 & 133.98 & 277.80 \\
\hline Liverpool & -288.39 & 114.92 & 117.48 & 133.92 & 171.42 & 249.35 \\
\hline Leicester & -288.39 & 125.20 & 134.53 & 109.80 & 152.68 & 233.83 \\
\hline Herefordshire & -288.39 & 122.83 & 115.62 & 72.49 & 135.67 & 158.22 \\
\hline Wokingham & -288.39 & 106.50 & 109.13 & 55.11 & 125.43 & 107.77 \\
\hline Scotland & -288.39 & 115.57 & 120.15 & 136.74 & 156.11 & 240.18 \\
\hline Aberdeen City & -288.39 & 118.02 & 124.79 & 150.60 & 161.15 & 266.16 \\
\hline Aberdeenshire & -288.39 & 114.41 & 128.96 & 118.51 & 137.28 & 210.77 \\
\hline Angus & -288.39 & 114.03 & 126.99 & 136.15 & 141.81 & 230.58 \\
\hline Argyll \& Bute & -288.39 & 111.90 & 125.71 & 117.57 & 152.00 & 218.79 \\
\hline Clackmannanshire & -288.39 & 115.61 & 105.77 & 154.92 & 157.72 & 245.63 \\
\hline Dumfries \& G’way & -288.39 & 114.99 & 115.39 & 107.43 & 144.48 & 193.91 \\
\hline Dundee City & -288.39 & 120.18 & 116.90 & 155.41 & 162.26 & 266.37 \\
\hline E. Ayrshire & -288.39 & 113.55 & 110.52 & 171.43 & 169.72 & 276.83 \\
\hline E. Dunbartonshire & -288.39 & 111.86 & 107.85 & 120.90 & 146.24 & 198.46 \\
\hline E. Lothian & -288.39 & 119.87 & 121.65 & 136.92 & 148.30 & 238.36 \\
\hline E. Renfrewshire & -288.39 & 116.16 & 122.00 & 126.67 & 150.77 & 227.22 \\
\hline Edinburgh, City of & -288.39 & 122.31 & 135.69 & 93.45 & 147.96 & 211.03 \\
\hline Eilean Siar & -288.39 & 120.01 & 145.66 & 54.25 & 157.19 & 188.72 \\
\hline Falkirk & -288.39 & 115.82 & 112.03 & 165.21 & 168.84 & 273.50 \\
\hline Fife & -288.39 & 119.15 & 125.25 & 132.43 & 154.78 & 243.22 \\
\hline Glasgow, City of & -288.39 & 116.02 & 126.41 & 176.91 & 174.58 & 305.53 \\
\hline Highland & -288.39 & 113.79 & 121.42 & 103.81 & 141.84 & 192.47 \\
\hline Inverclyde & -288.39 & 114.16 & 117.48 & 164.92 & 164.05 & 272.22 \\
\hline Midlothian & -288.39 & 112.41 & 108.43 & 157.82 & 151.53 & 241.80 \\
\hline Moray & -288.39 & 114.89 & 114.93 & 110.67 & 126.91 & 179.01 \\
\hline N. Ayrshire & -288.39 & 112.45 & 119.68 & 133.05 & 162.52 & 239.31 \\
\hline N. Lanarkshire & -288.39 & 108.70 & 100.32 & 188.02 & 179.74 & 288.38 \\
\hline Orkney Islands & -288.39 & 111.48 & 133.48 & 62.36 & 140.12 & 159.06 \\
\hline Perth \& Kinross & -288.39 & 119.43 & 127.80 & 110.09 & 137.94 & 206.87 \\
\hline Renfrewshire & -288.39 & 110.52 & 113.42 & 126.67 & 150.77 & 212.99 \\
\hline Scottish Borders & -288.39 & 119.08 & 120.96 & 129.44 & 133.48 & 214.57 \\
\hline Shetland Islands & -288.39 & 120.18 & 140.79 & 109.18 & 144.09 & 225.85 \\
\hline S. Ayrshire & -288.39 & 117.47 & 123.51 & 103.06 & 152.83 & 208.48 \\
\hline S. Lanarkshire & -288.39 & 112.93 & 110.06 & 145.77 & 165.75 & 246.11 \\
\hline Stirling & -288.39 & 114.13 & 118.29 & 119.27 & 157.48 & 220.78 \\
\hline W. Dunbartonshire & -288.39 & 115.82 & 104.61 & 117.57 & 152.00 & 201.60 \\
\hline W. Lothian & -288.39 & 105.43 & 107.85 & 176.11 & 167.66 & 268.66 \\
\hline
\end{tabular}


Table 6 FSS for Older People's Social Services, 2004-05: Part B

\begin{tabular}{|c|c|c|c|c|c|c|c|}
\hline & $\begin{array}{r}\text { Sum for older } \\
\text { people on } \\
\text { IS/IBJSA } \\
\text { £ per adult }\end{array}$ & $\begin{array}{r}\text { Sum for } \\
\text { pensioners } \\
\text { living alone } \\
\text { E per adult }\end{array}$ & $\begin{array}{r}\text { Sum for } \\
\text { people 65+ } \\
\text { on AA/DLA } \\
\text { £ per adult }\end{array}$ & $\begin{array}{l}\text { Sum for pen- } \\
\text { sioners not in } \\
\text { couple etc. } \\
£ \text { per adult }\end{array}$ & $\begin{array}{r}\text { Low } \\
\text { income } \\
\text { index }\end{array}$ & $\begin{array}{r}\text { Sum for } \\
\text { low income } \\
\text { adjustment } \\
\text { E per adult }\end{array}$ & $\begin{array}{r}\text { Total of } \\
\text { factors on } \\
\text { this table } \\
\text { E per adult }\end{array}$ \\
\hline England & 91.75 & 101.99 & 166.94 & 47.24 & 1.09 & 52.07 & 459.99 \\
\hline Tower Hamlets & 270.43 & 122.77 & 225.99 & 50.84 & 1.27 & 265.19 & 935.22 \\
\hline Westminster & 138.75 & 145.42 & 143.53 & 43.67 & 1.22 & 164.97 & 636.35 \\
\hline Liverpool & 178.70 & 111.62 & 279.47 & 62.24 & 1.17 & 148.07 & 780.11 \\
\hline Leicester & 161.62 & 105.37 & 190.63 & 57.18 & 1.12 & 92.23 & 607.03 \\
\hline Herefordshire & 61.87 & 89.15 & 159.72 & 52.17 & 1.07 & 36.11 & 399.02 \\
\hline Wokingham & 43.04 & 86.07 & 94.26 & 58.78 & 1.14 & 53.07 & 335.22 \\
\hline Scotland & 109.18 & 111.31 & 197.13 & 48.87 & 1.12 & 88.28 & 554.77 \\
\hline Aberdeen City & 89.64 & 116.43 & 186.19 & 42.91 & 1.11 & 73.78 & 508.95 \\
\hline Aberdeenshire & 76.37 & 103.13 & 157.38 & 49.86 & 1.14 & 82.22 & 468.96 \\
\hline Angus & 88.77 & 112.60 & 159.23 & 38.53 & 1.08 & 47.23 & 446.36 \\
\hline Argyll \& Bute & 86.57 & 113.44 & 168.52 & 48.63 & 1.10 & 61.75 & 478.91 \\
\hline Clackmannanshire & 97.95 & 111.57 & 157.31 & 45.77 & 1.12 & 79.18 & 491.78 \\
\hline Dumfries \& G'way & 87.03 & 102.14 & 163.51 & 50.55 & 1.10 & 56.85 & 460.08 \\
\hline Dundee City & 126.36 & 120.76 & 237.87 & 38.98 & 1.09 & 74.61 & 598.59 \\
\hline E. Ayrshire & 123.71 & 109.84 & 226.72 & 48.98 & 1.15 & 116.26 & 625.50 \\
\hline E. Dunbartonshire & 65.17 & 102.19 & 183.01 & 58.48 & 1.14 & 84.05 & 492.91 \\
\hline E. Lothian & 88.25 & 105.52 & 192.08 & 46.34 & 1.11 & 71.08 & 503.27 \\
\hline E. Renfrewshire & 64.11 & 110.05 & 175.16 & 50.73 & 1.11 & 71.26 & 471.31 \\
\hline Edinburgh, City of & 81.11 & 120.30 & 159.65 & 43.55 & 1.09 & 54.85 & 459.46 \\
\hline Eilean Siar & 172.44 & 93.92 & 163.91 & 94.08 & 1.22 & 153.45 & 677.80 \\
\hline Falkirk & 109.45 & 111.38 & 192.03 & 47.77 & 1.14 & 100.94 & 561.57 \\
\hline Fife & 79.67 & 109.74 & 163.98 & 40.94 & 1.08 & 51.58 & 445.91 \\
\hline Glasgow, City of & 189.73 & 123.62 & 262.94 & 51.41 & 1.17 & 157.72 & 785.42 \\
\hline Highland & 95.76 & 104.04 & 165.33 & 55.25 & 1.11 & 67.47 & 487.85 \\
\hline Inverclyde & 139.54 & 115.21 & 200.03 & 48.97 & 1.14 & 110.11 & 613.87 \\
\hline Midlothian & 79.39 & 98.97 & 204.59 & 53.65 & 1.15 & 104.20 & 540.81 \\
\hline Moray & 78.84 & 106.96 & 146.92 & 49.79 & 1.10 & 53.51 & 436.03 \\
\hline N. Ayrshire & 116.35 & 111.97 & 192.13 & 48.87 & 1.11 & 79.51 & 548.82 \\
\hline N. Lanarkshire & 143.00 & 106.50 & 251.27 & 58.67 & 1.20 & 170.16 & 729.60 \\
\hline Orkney Islands & 78.27 & 110.08 & 167.13 & 60.40 & 1.09 & 52.89 & 468.77 \\
\hline Perth \& Kinross & 75.14 & 106.34 & 165.68 & 43.36 & 1.07 & 41.64 & 432.15 \\
\hline Renfrewshire & 115.03 & 110.05 & 211.45 & 50.73 & 1.11 & 79.55 & 566.80 \\
\hline Scottish Borders & 78.27 & 113.03 & 165.47 & 38.75 & 1.07 & 42.52 & 438.06 \\
\hline Shetland Islands & 88.34 & 103.64 & 177.37 & 70.09 & 1.17 & 114.83 & 554.27 \\
\hline S. Ayrshire & 87.63 & 108.64 & 198.79 & 49.30 & 1.09 & 56.41 & 500.77 \\
\hline S. Lanarkshire & 126.12 & 104.86 & 228.93 & 54.07 & 1.14 & 109.53 & 623.51 \\
\hline Stirling & 83.54 & 108.46 & 181.09 & 49.22 & 1.10 & 64.89 & 487.20 \\
\hline W. Dunbartonshire & 153.09 & 113.44 & 238.81 & 48.62 & 1.10 & 73.37 & 627.33 \\
\hline W. Lothian & 124.52 & 108.62 & 233.09 & 49.90 & 1.16 & 122.27 & 638.41 \\
\hline
\end{tabular}


Table 7 FSS for Older People's Social Services, 2004-05: Part C

\begin{tabular}{|c|c|c|c|c|c|c|}
\hline & $\begin{array}{r}\text { Total from } \\
\text { Tables } \\
3 \text { and } 4 \\
\text { E per adult }\end{array}$ & $\begin{array}{r}\text { Sum } \\
\text { for } \\
\text { sparsity } \\
\text { E per adult }\end{array}$ & $\begin{array}{r}\text { Sum } \\
\text { For } \\
\text { ACA } \\
\text { £ per adult }\end{array}$ & $\begin{array}{r}\text { FSS } \\
\text { (after } \\
\text { scaling) } \\
\text { E per adult }\end{array}$ & $\begin{array}{r}\text { Adults 65+ } \\
\text { as \% of } \\
\text { total } \\
\text { population }\end{array}$ & $\begin{array}{r}\text { FSS } \\
\text { (after } \\
\text { scaling) } \\
\text { £ per head }\end{array}$ \\
\hline England & 662.20 & 0.99 & 29.10 & 692.30 & 15.50 & 107.32 \\
\hline Tower Hamlets & 1245.55 & 0.11 & 348.66 & $1,594.31$ & 8.83 & 140.83 \\
\hline Westminster & 914.15 & 0.14 & 255.91 & $1,170.19$ & 11.49 & 134.46 \\
\hline Liverpool & 1029.46 & 0.23 & 8.44 & $1,038.13$ & 14.96 & 155.35 \\
\hline Leicester & 840.85 & 0.17 & 0.00 & 841.02 & 12.97 & 109.11 \\
\hline Herefordshire & 557.24 & 9.00 & 0.00 & 566.24 & 18.76 & 106.25 \\
\hline Wokingham & 442.99 & 1.02 & 61.50 & 505.51 & 11.67 & 58.98 \\
\hline Scotland & 794.96 & 3.03 & 8.68 & 806.68 & 15.84 & 127.82 \\
\hline Aberdeen City & 775.10 & 0.76 & 0.00 & 775.86 & 15.25 & 118.34 \\
\hline Aberdeenshire & 679.72 & 8.30 & 58.41 & 746.43 & 14.31 & 106.83 \\
\hline Angus & 676.94 & 5.11 & 0.00 & 682.05 & 17.85 & 121.74 \\
\hline Argyll \& Bute & 697.70 & 7.98 & 0.00 & 705.68 & 18.18 & 128.32 \\
\hline Clackmannanshire & 737.41 & 1.63 & 0.00 & 739.04 & 14.61 & 107.97 \\
\hline Dumfries \& G’way & 653.99 & 7.77 & 0.00 & 661.76 & 19.30 & 127.71 \\
\hline Dundee City & 864.95 & 0.30 & 0.00 & 865.25 & 17.49 & 151.34 \\
\hline E. Ayrshire & 902.33 & 3.34 & 0.00 & 905.67 & 16.13 & 146.10 \\
\hline E. Dunbartonshire & 691.37 & 0.85 & 0.00 & 692.22 & 15.82 & 109.47 \\
\hline E. Lothian & 741.63 & 3.28 & 0.00 & 744.91 & 17.03 & 126.89 \\
\hline E. Renfrewshire & 698.52 & 0.71 & 0.00 & 699.23 & 15.73 & 109.96 \\
\hline Edinburgh, City of & 670.49 & 0.38 & 49.58 & 720.45 & 15.11 & 108.88 \\
\hline Eilean Siar & 866.52 & 22.63 & 0.00 & 889.14 & 19.89 & 176.86 \\
\hline Falkirk & 835.07 & 1.45 & 0.00 & 836.51 & 15.31 & 128.04 \\
\hline Fife & 689.14 & 1.89 & 0.00 & 691.03 & 16.36 & 113.09 \\
\hline Glasgow, City of & 1090.96 & 0.36 & 18.99 & $1,110.30$ & 15.44 & 171.38 \\
\hline Highland & 680.31 & 9.00 & 0.00 & 689.31 & 16.69 & 115.07 \\
\hline Inverclyde & 886.09 & 0.90 & 0.00 & 886.98 & 16.25 & 144.15 \\
\hline Midlothian & 782.61 & 2.30 & 0.00 & 784.91 & 15.05 & 118.09 \\
\hline Moray & 615.03 & 5.09 & 0.00 & 620.12 & 16.30 & 101.09 \\
\hline N. Ayrshire & 788.13 & 2.19 & 0.00 & 790.31 & 16.30 & 128.81 \\
\hline N. Lanarkshire & 1017.98 & 1.20 & 0.00 & $1,019.18$ & 13.76 & 140.21 \\
\hline Orkney Islands & 627.83 & 14.95 & 0.00 & 642.77 & 16.59 & 106.66 \\
\hline Perth \& Kinross & 639.02 & 5.76 & 0.00 & 644.77 & 18.47 & 119.12 \\
\hline Renfrewshire & 779.80 & 0.86 & 0.00 & 780.65 & 15.34 & 119.78 \\
\hline Scottish Borders & 652.63 & 7.24 & 0.00 & 659.87 & 18.47 & 121.87 \\
\hline Shetland Islands & 780.13 & 18.74 & 0.00 & 798.87 & 14.33 & 114.51 \\
\hline S. Ayrshire & 709.25 & 2.69 & 0.00 & 711.94 & 18.96 & 134.97 \\
\hline S. Lanarkshire & 869.62 & 2.25 & 0.00 & 871.86 & 15.44 & 134.62 \\
\hline Stirling & 707.98 & 4.01 & 0.00 & 711.99 & 15.49 & 110.32 \\
\hline W. Dunbartonshire & 828.93 & 0.87 & 0.00 & 829.80 & 15.29 & 126.87 \\
\hline W. Lothian & 907.07 & 1.82 & 0.00 & 908.89 & 11.65 & 105.90 \\
\hline
\end{tabular}


Table 8 FSS for Younger Adult's Social Services, 2004-05

\begin{tabular}{|c|c|c|c|c|c|c|c|}
\hline & $\begin{array}{r}\text { Basic } \\
\text { amount } \\
E \text { per } \\
\text { adult }\end{array}$ & $\begin{array}{r}\text { Sum for } \\
\text { adults on } \\
\text { IS/IBJSA } \\
\text { E per adult }\end{array}$ & $\begin{array}{r}\text { Sum for } \\
\text { households } \\
\text { with no family } \\
\text { } \text { per adult }\end{array}$ & $\begin{array}{r}\text { Sum for rent- } \\
\text { ing public } \\
\text { sector flats } \\
\text { E per adult }\end{array}$ & $\begin{array}{r}\text { Sum for } \\
\text { ACA } \\
\text { E per } \\
\text { adult }\end{array}$ & $\begin{array}{r}\text { FSS (after } \\
\text { scaling) } \\
£ \text { per } \\
\text { adult }\end{array}$ & $\begin{array}{r}\text { Adults 18- } \\
64 \text { as \% of } \\
\text { total } \\
\text { population }\end{array}$ \\
\hline England & 47.61 & 18.99 & 28.83 & 9.02 & 5.75 & 110.19 & 61.72 \\
\hline Tower Hamlets & 47.61 & 38.88 & 40.59 & 62.40 & 47.43 & 236.92 & 66.97 \\
\hline Westminster & 47.61 & 23.72 & 54.38 & 22.76 & 37.16 & 185.65 & 74.08 \\
\hline Liverpool & 47.61 & 48.22 & 33.62 & 12.31 & 1.11 & 142.87 & 62.59 \\
\hline Leicester & 47.61 & 29.12 & 31.87 & 11.14 & 0.00 & 119.75 & 62.40 \\
\hline Herefordshire & 47.61 & 13.15 & 25.89 & 5.57 & 0.00 & 92.22 & 58.96 \\
\hline Wokingham & 47.61 & 4.65 & 20.97 & 2.70 & 9.35 & 85.29 & 64.64 \\
\hline Scotland & 47.61 & 24.28 & 30.14 & 20.40 & 1.41 & 123.84 & 62.44 \\
\hline Aberdeen City & 47.61 & 17.13 & 34.31 & 26.25 & 0.00 & 125.30 & 66.10 \\
\hline Aberdeenshire & 47.61 & 10.44 & 23.66 & 6.12 & 6.67 & 94.51 & 62.01 \\
\hline Angus & 47.61 & 18.60 & 28.31 & 17.18 & 0.00 & 111.70 & 60.41 \\
\hline Argyll \& Bute & 47.61 & 18.48 & 30.02 & 16.91 & 0.00 & 113.02 & 60.38 \\
\hline Clackmannanshire & 47.61 & 25.73 & 26.38 & 16.82 & 0.00 & 116.54 & 62.01 \\
\hline Dumfries \& G’way & 47.61 & 19.77 & 28.52 & 8.87 & 0.00 & 104.77 & 59.30 \\
\hline Dundee City & 47.61 & 34.82 & 35.05 & 33.97 & 0.00 & 151.46 & 62.09 \\
\hline E. Ayrshire & 47.61 & 29.28 & 26.60 & 18.26 & 0.00 & 121.75 & 61.49 \\
\hline E. Dunbartonshire & 47.61 & 12.41 & 24.22 & 19.54 & 0.00 & 103.79 & 61.03 \\
\hline E. Lothian & 47.61 & 15.77 & 27.72 & 11.55 & 0.00 & 102.66 & 59.52 \\
\hline E. Renfrewshire & 47.61 & 12.63 & 26.63 & 22.43 & 0.00 & 109.31 & 60.00 \\
\hline Edinburgh, City of & 47.61 & 19.11 & 38.61 & 18.72 & 8.22 & 132.28 & 66.33 \\
\hline Eilean Siar & 47.61 & 22.51 & 33.26 & 3.12 & 0.00 & 106.51 & 58.74 \\
\hline Falkirk & 47.61 & 21.96 & 27.84 & 22.84 & 0.00 & 120.25 & 62.64 \\
\hline Fife & 47.61 & 21.77 & 27.38 & 15.85 & 0.00 & 112.61 & 61.64 \\
\hline Glasgow, City of & 47.61 & 46.25 & 38.91 & 44.48 & 2.85 & 180.12 & 64.01 \\
\hline Highland & 47.61 & 18.80 & 29.01 & 5.43 & 0.00 & 100.85 & 61.15 \\
\hline Inverclyde & 47.61 & 33.81 & 30.15 & 32.37 & 0.00 & 143.95 & 61.42 \\
\hline Midlothian & 47.61 & 17.25 & 23.97 & 9.22 & 0.00 & 98.06 & 61.50 \\
\hline Moray & 47.61 & 14.58 & 28.38 & 6.03 & 0.00 & 96.61 & 61.01 \\
\hline N. Ayrshire & 47.61 & 31.24 & 27.95 & 12.48 & 0.00 & 119.29 & 61.11 \\
\hline N. Lanarkshire & 47.61 & 29.18 & 25.80 & 28.41 & 0.00 & 131.01 & 63.02 \\
\hline Orkney Islands & 47.61 & 11.51 & 30.43 & 1.26 & 0.00 & 90.81 & 60.67 \\
\hline Perth \& Kinross & 47.61 & 14.37 & 30.34 & 12.06 & 0.00 & 104.37 & 59.92 \\
\hline Renfrewshire & 47.61 & 26.25 & 26.63 & 22.43 & 0.00 & 122.93 & 62.61 \\
\hline Scottish Borders & 47.61 & 14.76 & 32.91 & 14.00 & 0.00 & 109.27 & 59.93 \\
\hline Shetland Islands & 47.61 & 10.37 & 28.21 & 3.12 & 0.00 & 89.31 & 61.42 \\
\hline S. Ayrshire & 47.61 & 22.96 & 28.92 & 14.04 & 0.00 & 113.54 & 60.20 \\
\hline S. Lanarkshire & 47.61 & 24.04 & 24.47 & 16.92 & 0.00 & 113.06 & 62.41 \\
\hline Stirling & 47.61 & 17.33 & 28.87 & 13.60 & 0.00 & 107.41 & 62.26 \\
\hline W. Dunbartonshire & 47.61 & 35.72 & 30.02 & 16.91 & 0.00 & 130.26 & 61.79 \\
\hline W. Lothian & 47.61 & 20.54 & 22.99 & 13.95 & 0.00 & 105.09 & 63.90 \\
\hline
\end{tabular}


Table 9 Total FSS for Social Services and Total GAE for Social Work, 2004-05

\begin{tabular}{|c|c|c|c|c|c|c|c|}
\hline & $\begin{array}{r}\text { Younger } \\
\text { adults FSS } \\
\text { (after scaling) } \\
\text { £ per head }\end{array}$ & $\begin{array}{r}\text { Children's } \\
\text { FSS (after } \\
\text { scaling) } \\
\text { E per head }\end{array}$ & $\begin{array}{r}\text { Older } \\
\text { people's FSS } \\
\text { (after scaling) } \\
\text { £ per head }\end{array}$ & \begin{tabular}{|r|} 
Total social \\
services \\
FSS \\
E per head
\end{tabular} & $\begin{array}{c}\text { Relative } \\
\text { FSS } \\
\text { per wor } \\
\text { head } £ \text { p }\end{array}$ & $\begin{array}{r}\text { Total } \\
\text { social } \\
\text { rk GAE } \\
\text { er head }\end{array}$ & $\begin{array}{r}\text { Relative } \\
\text { GAE } \\
\text { per } \\
\text { head }\end{array}$ \\
\hline England & 68.01 & 75.41 & 107.32 & 250.74 & - & - & - \\
\hline Tower Hamlets & 158.66 & 300.62 & 140.83 & 600.11 & - & - & - \\
\hline Westminster & 137.54 & 160.89 & 134.46 & 432.89 & - & - & - \\
\hline Liverpool & 89.42 & 126.69 & 155.35 & 371.46 & - & - & - \\
\hline Leicester & 74.72 & 105.50 & 109.11 & 289.33 & - & - & - \\
\hline Herefordshire & 54.37 & 44.45 & 106.25 & 205.07 & - & - & - \\
\hline Wokingham & 55.13 & 31.97 & 58.98 & 146.08 & - & - & - \\
\hline Scotland & 77.32 & 83.92 & 127.82 & 289.07 & 1.00 & 352.54 & 1.00 \\
\hline Aberdeen City & 82.82 & 74.41 & 118.34 & 275.57 & 0.95 & 347.18 & 0.98 \\
\hline Aberdeenshire & 58.61 & 41.44 & 106.83 & 206.88 & 0.72 & 288.41 & 0.82 \\
\hline Angus & 67.47 & 61.00 & 121.74 & 250.21 & 0.87 & 379.81 & 1.08 \\
\hline Argyll \& Bute & 68.24 & 70.77 & 128.32 & 267.33 & 0.92 & 376.76 & 1.07 \\
\hline Clackmannanshire & 72.26 & 81.24 & 107.97 & 261.47 & 0.90 & 323.39 & 0.92 \\
\hline Dumfries \& G’way & 62.13 & 52.91 & 127.71 & 242.76 & 0.84 & 350.01 & 0.99 \\
\hline Dundee City & 94.04 & 119.72 & 151.34 & 365.11 & 1.26 & 412.81 & 1.17 \\
\hline E. Ayrshire & 74.87 & 81.10 & 146.10 & 302.06 & 1.04 & 368.46 & 1.05 \\
\hline E. Dunbartonshire & 63.34 & 67.83 & 109.47 & 240.65 & 0.83 & 274.34 & 0.78 \\
\hline E. Lothian & 61.10 & 62.74 & 126.89 & 250.73 & 0.87 & 345.45 & 0.98 \\
\hline E. Renfrewshire & 65.59 & 79.04 & 109.96 & 254.59 & 0.88 & 292.16 & 0.83 \\
\hline Edinburgh, City of & 87.74 & 94.97 & 108.88 & 291.59 & 1.01 & 351.58 & 1.00 \\
\hline Eilean Siar & 62.56 & 30.91 & 176.86 & 270.33 & 0.94 & 468.54 & 1.33 \\
\hline Falkirk & 75.32 & 73.84 & 128.04 & 277.20 & 0.96 & 336.67 & 0.95 \\
\hline Fife & 69.41 & 74.73 & 113.09 & 257.23 & 0.89 & 342.37 & 0.97 \\
\hline Glasgow, City of & 115.29 & 164.09 & 171.38 & 450.76 & 1.56 & 425.02 & 1.21 \\
\hline Highland & 61.67 & 51.42 & 115.07 & 228.16 & 0.79 & 340.33 & 0.97 \\
\hline Inverclyde & 88.42 & 111.45 & 144.15 & 344.01 & 1.19 & 393.89 & 1.12 \\
\hline Midlothian & 60.30 & 65.76 & 118.09 & 244.16 & 0.84 & 325.48 & 0.92 \\
\hline Moray & 58.94 & 46.24 & 101.09 & 206.26 & 0.71 & 315.63 & 0.90 \\
\hline N. Ayrshire & 72.89 & 85.70 & 128.81 & 287.40 & 0.99 & 370.19 & 1.05 \\
\hline N. Lanarkshire & 82.56 & 93.61 & 140.21 & 316.37 & 1.09 & 322.26 & 0.91 \\
\hline Orkney Islands & 55.09 & 30.86 & 106.66 & 192.60 & 0.67 & 349.26 & 0.99 \\
\hline Perth \& Kinross & 62.54 & 57.99 & 119.12 & 239.65 & 0.83 & 369.41 & 1.05 \\
\hline Renfrewshire & 76.96 & 83.58 & 119.78 & 280.32 & 0.97 & 347.89 & 0.99 \\
\hline Scottish Borders & 65.48 & 49.46 & 121.87 & 236.82 & 0.82 & 365.05 & 1.04 \\
\hline Shetland Islands & 54.86 & 34.80 & 114.51 & 204.17 & 0.71 & 350.63 & 0.99 \\
\hline S. Ayrshire & 68.35 & 60.27 & 134.97 & 263.59 & 0.91 & 373.61 & 1.06 \\
\hline S. Lanarkshire & 70.56 & 65.93 & 134.62 & 271.11 & 0.94 & 335.84 & 0.95 \\
\hline Stirling & 66.87 & 65.31 & 110.32 & 242.51 & 0.84 & 333.84 & 0.95 \\
\hline W. Dunbartonshire & 80.49 & 92.49 & 126.87 & 299.85 & 1.04 & 374.15 & 1.06 \\
\hline W. Lothian & 67.16 & 72.82 & 105.90 & 245.88 & 0.85 & 283.67 & 0.80 \\
\hline
\end{tabular}

